The International Journal of Indian Psychology: Volume: 01 | Issue: 04 No. 2 | ISSN 2348-5396

\title{
Marital Adjustment of Tribal and Non-Tribal Women
}

\author{
Rathod Chirag R.*, Patel Hiren**
}

\begin{abstract}
:
The present study related to Adjustment level of Tribal and non Tribal Total 120 Marital's were selected randomly from Panchmahal district area's randomly. In which 60 marital (30 women aged 21 to 30 year and 30 women aged 31 to 40 year) from Tribal and also 60 marital (30 women aged 21 to 30 years and 30 women aged 31 t0 40 year) from non tribal. After analysis was done according to key for the comparison of difference group ' $t$ ' test was calculated.

\section{INTRODUCTION:}

A good start can be made by studying the implications of good and bad adjustment to marriage. There is, for example, the fact that in this country every year there are almost 400,000 divorces; and it is estimated that in ten years one out of every three marriages will terminate in divorce, unless an effective remedy for marital discord is worked out in the meantime. In addition, there are countless homes internally disrupted by incessant quarreling, dissension, hostility, jealousy, bad discipline, and the like. Divorced couples and psychologically broken homes represent appalling social waste and widespread marital and family maladjustments. It is obvious that where two people find it impossible to abide by marriage vows or where the family is disrupted by internal conflict it is impossible to speak any longer of good adjustment.

The number of persons involved in marital discord must run into the millions; and when to this figure we add the number of children adversely affected by the breakup of the family, the total is staggering. Nor is there any hope that perhaps children will in some way escape the effects of family discord; too many studies show a close relation between children's maladjustments and the breakup of the family.
\end{abstract}

*\&**, M.A. Clinical Psychology, S.P.University, VallabhVidyanagar, Gujarat 
The International Journal of Indian Psychology: Volume: 01 | Issue: 04 No. 2 | ISSN 2348-5396

The unfortunate part of this relation is that unhappy and emotionally disturbed children become unhappy, disturbed adults who in their turn will contribute to the continuing increase of family disintegration, unless the principles of good marital adjustment are put into application on a wide scale. The effects of marital adjustment are put into application on a wide scale. The effects of marital and family maladjustments on society are just as disturbing, since no society can be healthier than its individual members. Unless, therefore, the vicious circle of maladjustmentbreakup-maladjustment is broken at some point by a thoroughgoing mental-hygiene program, we can expect society to continue disintegrating at an accelerated rate.

The individual and social effects of marital and family discord are only the more obvious parts of the picture. Of even greater importance in numerous instances are the moral and religious consequences. Moral disintegration and loss of religious beliefs and practices often have their beginning in the psychologically disrupted home. It is difficult for parents eternally at odds with each other to establish or to enforce moral and religious standards and practices. In such situations, authority and whole some discipline rapidly disintegrate; the practice of setting good examples becomes impossibility; and the healthy influence that parents can exert on children fails to materialize.

\section{Meaning of marital adjustment}

The concept of marital adjustment refers essentially to the art of living effectively and wholesomely within the framework of responsibilities, relations and expectancies that constitute the state of marriage. It means the ability to meet the day-to-day demands vicissitudes, and responsibilities of marriage with whatever degree of emotional equanimity and efficiency is required at the time. It involves getting along activities of the family group, accepting additionalresponsibilities an they arise, and changing one's style of life to correspond with changes in family life.

\section{Fitness for marriage}

1. Economic fitness

2. Emotional fitness

3. Sexual fitness

4. Reproductive fitness

5. General health

\section{Nature of the problem of marital adjustment}

Marital adjustment is different in several important respects from other aspect of human adjustment. First of all, there is the peculiar circumstance, rarely found in other situation, that 
The International Journal of Indian Psychology: Volume: 01 | Issue: 04 No. 2 | ISSN 2348-5396

marriage requires the adjustment of a person to one other person. We have many friend and acquaintances but only me husband or one wife. The better the chances of making an effective adjustment, since ifwe have difficulty in one group we can turn to another for the expression of needs and interests or the reduction of frustration.

\section{Importance of studying woman.}

Throughout the history of mankind woman have been given crucial importance in the Indian society. Goddess Durga is considered the goddess of power, goddess Laxmia symbol of wealth, and goddess saraswati asymbol of wisdom and intellect. The cultural heritage of India has passed from generation to generation through the help of woman. A historical study of womanin India reveals that there have been distinct stages of rise and fall in their low status. Woman in Vedic times enjoyed a very high status, specially in matters of marriage and selecting the life partners. Woman had equal rights and in "swayamvara" woman were given chance to select their partners. The system of widow remarriage was in existence, Vedic woman had voice in marriage, and love marriage, remarriage, levirate and sororate kind of marriage, ect. Consent of elders was in vogue. "Rig-veda does not mention any were the practice of the burning of widow with their read husband."

\section{Woman in historical perspective.}

After the Vedic period the position of woman deteriorated considerably. The hindu law giver Manu had made woman entirely dependent on man and subjected her to the authority of a father, husband and son on the different periods of her life, such as daughter wife and mother in short, there was that, "for woman there can be no freedom at any stage in life." This position it was reinforced by the muslim masters, whose customs and traditions were noted for the complete subordination of woman by man, and considered woman as inferior to man. They had to lead clostered life and had to move within the narrow sphere of kitchen cooking child bearing-rearing and catering to the relatives, in-laws and husband comprised their work, life and activity. They had practically no idea of the busy world except what they heard from their menfolk.

\section{OBJECTIVES :}

1. To know the difference of Adjustment at woman provided is Trible and non-Trible woman.

2. To know the difference of Adjustment at woman Age between 21 to 30 years and 31 to 40 years. 
The International Journal of Indian Psychology: Volume: 01 | Issue: 04 No. 2 | ISSN 2348-5396

\section{HYPOTHESIS:}

1. There are no different in Adjustment level of Tribal woman from 21 to 30 and 31 to 40 ages.

2. There are no different in Adjustment level of non-tribal woman from 21 to 30 and 31 to 40 ages.

3. There are no different in Adjustment level of Tribal and non Tribal woman.

\section{Variable:}

$\begin{array}{ll}* & \mathrm{~A}=\text { Woman's } \\ & \mathrm{A}_{1}=\text { Tribal woman } \\ & \mathrm{A}_{2}=\text { non Tribal woman } \\ * * & \mathrm{~B}=\text { Age } \\ & \mathrm{B}_{1}=21 \text { to } 30 \text { year } \\ & \mathrm{B}_{2}=31 \text { to } 40 \text { year. } \\ * & \mathrm{~A}=\text { Independent variable } \\ * * & \mathrm{~B}=\text { Dependent variable }\end{array}$

Sampling:

\begin{tabular}{|l|l|l|l|}
\hline & \multicolumn{1}{|c|}{ Age } & \multicolumn{1}{c|}{ Age } & \\
\hline Woman & 21 to 30 & 31 to 40 & Total \\
\hline Tribal & 30 & 30 & 60 \\
\hline Non-Tribal & 30 & 30 & 60 \\
\hline Total : & 60 & 60 & 120 \\
\hline
\end{tabular}

Tools :

In this study Adjustment questioner where used from the data collection contracted by P. Kumar and K. Rohit.

\section{Research design:}

120 marital woman were selected randomly Panchmahal district areas. Woman was divided in two groups. Group one Tribal in which 60 women (30 woman 21 to 30 year and 30 women 31 to 40 year). Number of two group Non-tribal woman in which 60 women (30 women 21 to 30 year and 30 women 31 to 40 year.)

$>$ After collecting 21 to 30 year and 30 women 31 to 40 year.

$>$ After collecting 21 to 30 year and 30 women 31 to 40 year.

$>$ After collecting the data statistical and analysis was done according to key for the comparison of different groups ' $\mathrm{T}$ ' test was calculated. 
The International Journal of Indian Psychology: Volume: 01 | Issue: 04 No. 2 | ISSN 2348-5396

RESULT AND DISCUSSION:

Table - 1: Tribal woman age from 21 to 30 and 31 to 40 years

Tribal

\begin{tabular}{|c|l|l|l|l|l|l|}
\hline Groups & \multicolumn{1}{|c|}{ N } & \multicolumn{1}{|c|}{ Mean } & \multicolumn{1}{c|}{ SD } & SEM & t & \multicolumn{1}{c|}{ Level } \\
\hline 21 to 30 & 30 & 20.37 & 4.48 & 0.82 & 0.5294 & $\begin{array}{l}\text { NS. } \\
0.01\end{array}$ \\
\hline 31 to 40 & 30 & 21.00 & 7.79 & 0.87 & & \\
\hline
\end{tabular}

This table indicates no significant different between 21 to 30 age and 31 to 40 age from Tribal woman. 21 to 30 ages are no effective in marital Adjustment Level.

Table - 2: Non Tribal woman age from 21 to 30 and 31 to 40 years

Non-Tribal

\begin{tabular}{|c|l|l|l|l|l|l|}
\hline Groups & \multicolumn{1}{|c|}{ N } & \multicolumn{1}{c|}{ Mean } & \multicolumn{1}{c|}{ SD } & SEM & t & \multicolumn{1}{c|}{ Level } \\
\hline 21 to 30 & 30 & 20.97 & 2.94 & 0.54 & 0.6635 & $\begin{array}{l}\text { NS. } \\
0.01\end{array}$ \\
\hline 31 to 40 & 30 & 21.43 & 2.49 & 0.45 & \multicolumn{2}{|c|}{$\mathrm{df}=58$, Sed $\mathrm{f}=0.703$} \\
\hline
\end{tabular}

This table indicates no significant difference between 21 to 30 and 31 to 40 age from Non-Tribal woman. 31 to 40 ages are more effective in marital Adjustment level.

Table - 3: All over Tribal and non-tribal marital woman.

Tribal \& Non-Tribal

\begin{tabular}{|l|l|l|l|l|l|l|}
\hline \multicolumn{1}{|c|}{ Groups } & \multicolumn{1}{|c|}{$\mathbf{N}$} & \multicolumn{1}{c|}{ Mean } & \multicolumn{1}{c|}{ SD } & SEM & t & \multicolumn{1}{c|}{ Level } \\
\hline Tribal & 60 & 20.68 & 4.60 & 0.59 & 0.7490 & $\begin{array}{l}\text { NS. } \\
.01\end{array}$ \\
\hline Non-Tribal & 60 & 21.20 & 2.71 & 0.35 & & \\
\hline
\end{tabular}

\section{Interpretation of tables and testing of hypothesis.}

$\mathrm{H}_{01} \quad$ There is no significant effect of Adjustment level between 21 to 30 and 31 to 40 age of Tribal woman group. Tested 't' value is 0.5294 at 0.01 levels. So, we accepted of this null hypothesis.

$\mathrm{H}_{02}$ There is no significant effect of Adjustment level between 21 to 30 and 31 to 40 age of Non-Tribal woman group. Tested ' $t$ ' value is 0.6635 at 0.01 levels. So, we accepted of this null hypothesis.
(C) 2014 www.ijip.in
July-September 2014
$63 \mid \mathrm{P}$ a g e 
The International Journal of Indian Psychology: Volume: 01 | Issue: 04 No. 2 | ISSN 2348-5396

$\mathrm{H}_{03} \quad$ There is no significant effect of Adjustment level between 21 to 30 and 31 to 40 age of Tribal \& Non-Tribal woman group. Tested 't' value is 0.7490 at 0.01 levels. So, we accepted of this null hypothesis.

\section{REFERENCES:}

1. Alexander A. Schneiders, Personal Adjustment and Mental Health. New York: Holt, Rinehart and Winston.1964.

2. Bernhard, H.W. To ward better personal adjustment, New York: Mc. GrawHill, 1951. Chaps. XII.

3. Magner, J.A. The art of Kappy Marriage, Nilwaukee: Bruce, 1947.

4. Mckineey, F. Psychology of Personal adjustment. ( ${ }^{\text {nd }}$ Ed.) New York: Wiley, 1949.I-IVIX,X, XIII.
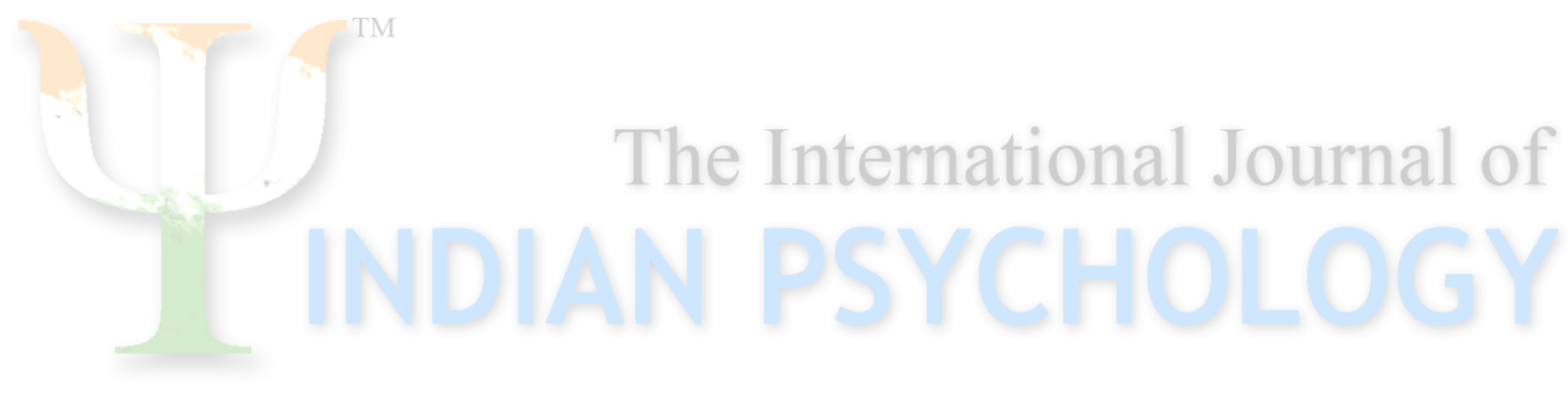